\title{
Dominating the Landscape - the emblematic Setting of Borgring and the Viking Age Ring Fortresses of Denmark
}

\author{
Jens Ulriksen ${ }^{1,3}$, Maja K. Schultz ${ }^{1}$ and Morten F. Mortensen ${ }^{2}$ \\ ${ }^{1}$ Museum Southeast Denmark, Algade 97, 4760 Vordingborg, Denmark. \\ ${ }^{2}$ Environmental Archaeology and Materials Science, the National Museum of Denmark, I.C.Modewegsvej, 2800 Lyngby, Denmark. \\ ORCID 0000-0002-4167-8227. \\ ${ }^{3}$ Corresponding author (ju@museerne.dk), ORCID 0000-0002-0341-6410.
}

\section{ABSTRACT}

This study explores the underlying reasons behind the construction and topographical location of the Viking Age ring fortress, Borgring near Køge, and the impact it had on the society on a regional scale. A key question is whether this manifestation of power is also expressing a disruption of the existing power structure in the region. The evidence from Borgring will be compared to the other four ring fortresses as well as other fortifications and large structures of the Viking Age in Denmark. In the end we will propose a new theory explaining that the Viking Age ring fortresses along with other monumental structures dated to the reign of King Harald Bluetooth (ca. AD 958-AD 986/987) represent a symbolic manifestation of a new order of society instigated by the conversion of the King in AD 963. More than being military strongholds the shape, the size and the positioning of the structures in the landscape were premeditated to impress both locals and travellers following important roads throughout the realm and to remind them of the King's presence and his power based on a new ideology.
\end{abstract}

ARTICLE HISTORY

Received 24 Sep-

tember 2019;

Accepted 15 June 2020

\section{KEYWORDS}

Viking Age; Ring fortress; Conversion; Power structure; Roads: Transport corridors.

\section{Introduction}

Since the discovery of the first Viking Age geometrical ring fortress in Denmark in the 1930ties, the size and design have nourished the perception that they have been military fortifications, either suppressing the local population or being strongholds and barracks for soldiers and naval forces (e. g. Andersen 1988; Holst et al. 2012, 494; Nielsen 1990, 145; Nørlund 1948, 160; Olsen and Schmidt 1977, 96; Roesdahl and Sindbæk 2014, 453-462). However, the excavations of Borgring at Køge, Denmark, between 2016 and 2018 (Christensen et al. in prep.; Jessen et al. in prep.; Ljungkvist et al. in prep.; Mortensen et al. in prep.) have prompted a reassessment of the alleged military aspect of the Danish ring fortresses.

The hypothesis of this study is that the Viking Age ring fortresses along with other monumental structures dated to the reign of Harald Bluetooth represent an emblematic manifestation of a new order of society instigated by the conversion of the King in AD 963. The shape, the size and the location of the structures in the landscape were premeditated to impress both locals and travellers following important roads throughout the realm and to remind them of the King's presence and his reign based on a new ideology.

The study will investigate, if the construction of Borgring and the concurrent manifestation of a new ruler ideology had an impact on the regional society. We will explore the strategic use of the terrain when placing Borgring and compare the evidence with other monumental structures of the late $10^{\text {th }}$ century Denmark. Consequently, we will propose a new theory of the role of the ring fortresses and related constructions (Figure 1).

\section{The Topography of East Zealand}

The topography of the region surrounding Borgring varies from relatively flat loamy moraine to a more undulating dead ice landscape with extensive woodlands. To the north of the Køge Stream the topography is characterised by an even, very fertile arable land towards Roskilde Fjord and along the Bay of Køge to the east (Figure 2). To the west and northwest of Borgring there is a pro- 


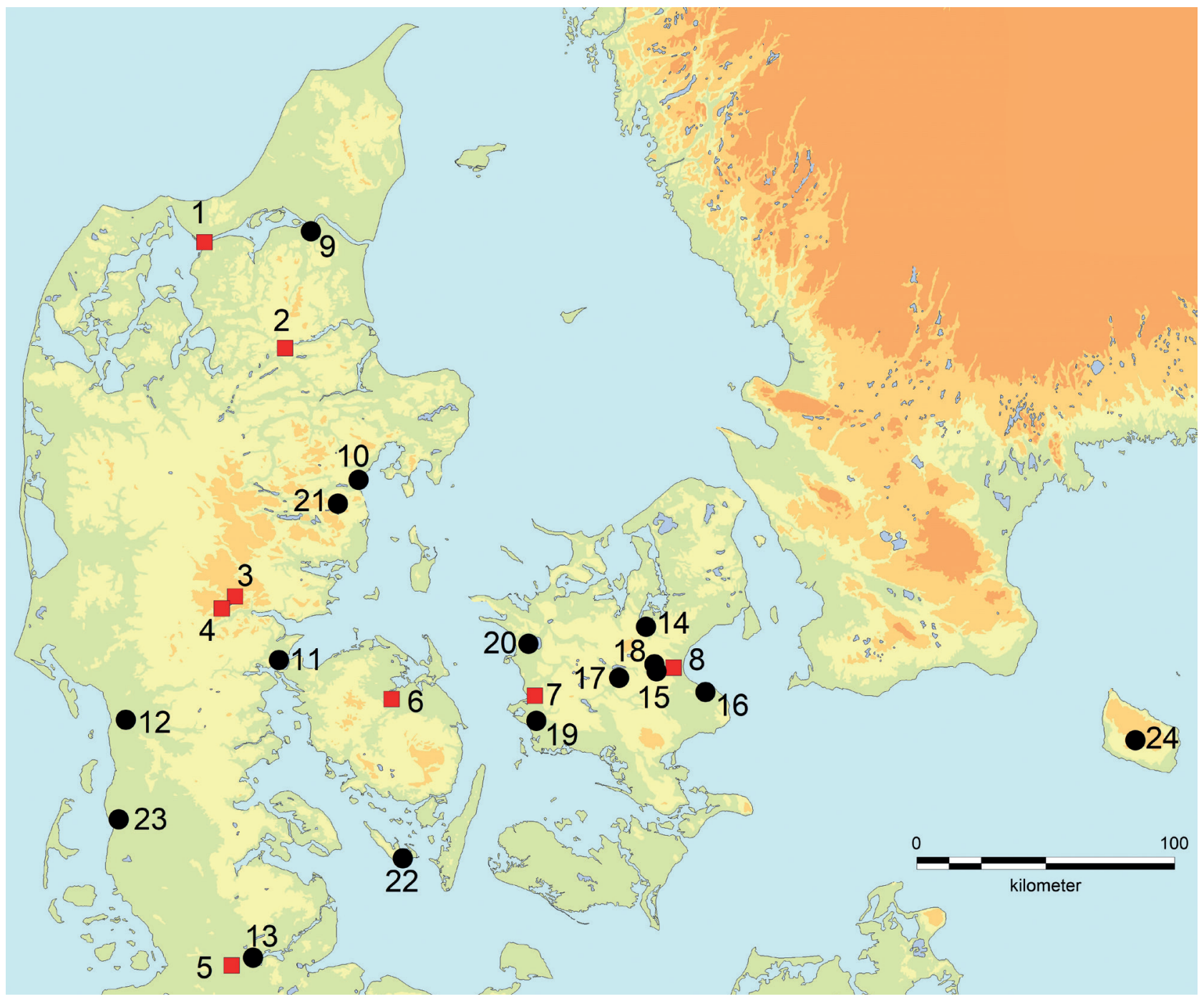

Figure 1. Harald Bluetooth's monumental constructions (red squares). 1) Aggersborg. 2) Fyrkat. 3) Jelling. 4) Ravning Enge. 5) Kovirke/Dannevirke. 6) Nonnebakken. 7) Trelleborg. 8) Borgring. Other sites mentioned in the text (black dots): 9) Aalborg. 10) Aarhus. 11) Erritsø. 12) Ribe. 13) Hedeby. 14) Lejre. 15) Ågård. 16) Strøby-Toftegård. 17) Ringsted. 18) Dalby Sø. 19) Boeslunde. 20). Tissø. 21) Trælborg. 22) Sankt Alberts. 23) Trælbanke. 24) Gamleborg.

nounced dead-ice landscape with numerous pools, ponds and drenched hollows. South of the Køge Stream the terrain is dominated by flat arable land shifting with less dramatic dead-ice profiles in the southeast.

A comparison of pollen records shows a near identical vegetation development in the region from the early Holocene until the Late Bronze Age. The developmental similarities cease in the Late Bronze Age when a massive deforestation is seen on the flat, fertile loamy moraine of eastern Zealand, while the woodlands persist on the hilly inland where it is more difficult to cultivate. Focusing on the period from the late Iron Age until the Early Medieval Period it is clear that the landscape sur- rounding Borgring was dominated by open grassland (Mortensen et al. in prep. A) (Figure 3).

\section{The Power Structure in Viking Age East Zealand}

It seems evident that the establishing of Borgring was a demonstration of power by the King of the Danes. Even though the construction of the ring fortress apparently did not have an immediate and significant influence on the regular settlements (Schultz et al. in prep.), the mark of the Christian king inflicted on the existing structure of power in East Zealand. Both the existing power structure and the transformation of it are reflected in the 


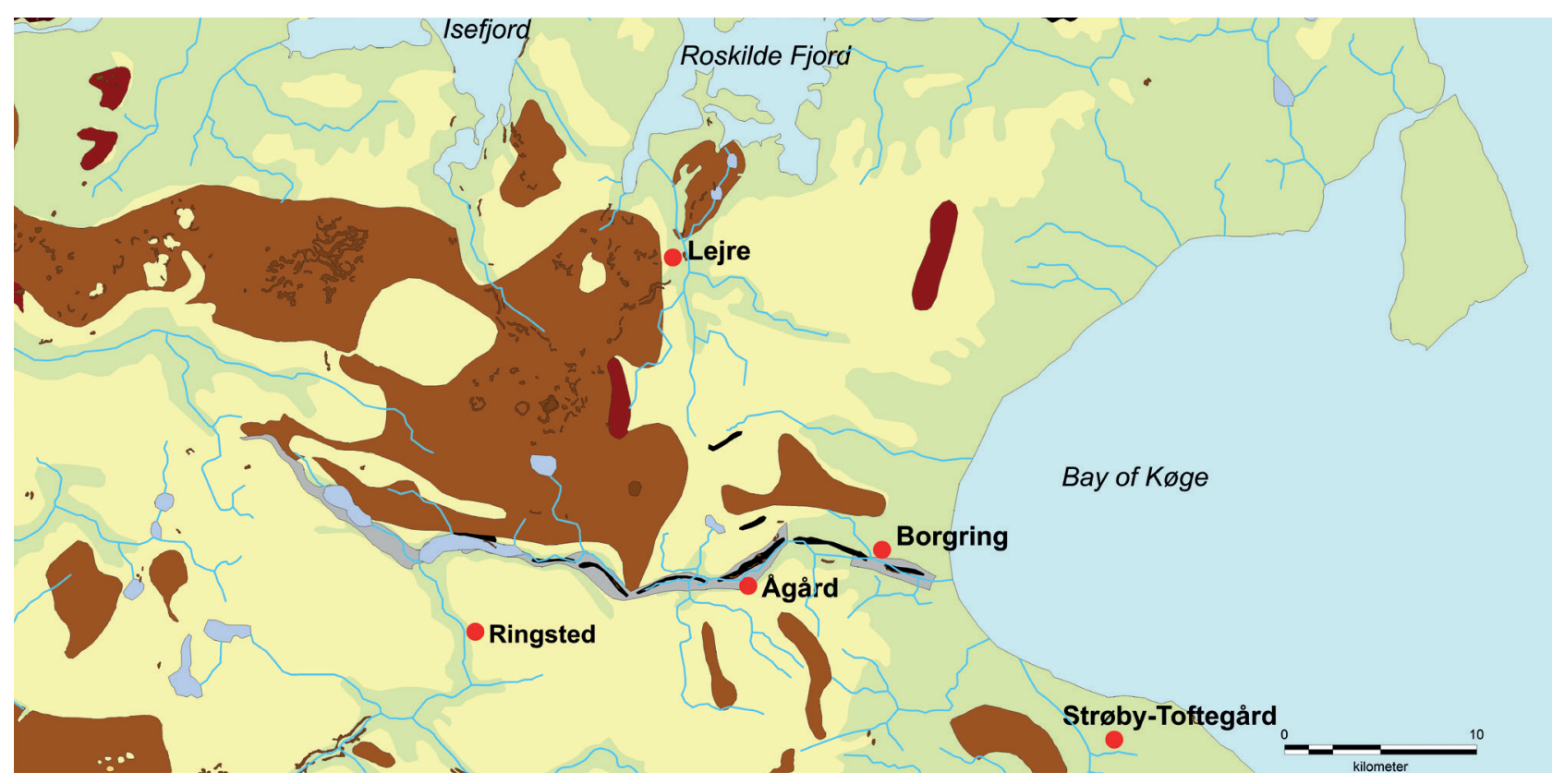

Figure 2. The principal geological surface of central East Zealand. Brown colours: dead ice and lateral moraine. Grey: tunnel valley. Black: esker. Yellow: terrain between 30 and $80 \mathrm{~m}$ a.s.l.

two distinctive residential sites of the region, Lejre and Strøby-Toftegård (cf. Figure 2).

Lejre is located $19 \mathrm{~km}$ to the north of Borgring and was the central place of East Zealand from the $5^{\text {th }}$ or $6^{\text {th }}$ century $A D$ to the late $10^{\text {th }}$ century $A D$ (Christensen 2007 and 2015). Topographically, Lejre sits in a border zone between a fertile and even terrain with numerous settlements to the east and a relatively uninviting and uninhabited pronounced dead-ice landscape to the west (Figure 4).

Lejre is generally recognized as a central cult place materialized by two large heaps of scorched stones mixed with animal bones, which are suggested to be 'hörgr', i. e. shrines for offerings. In addition, the pronounced dead-ice topography to the west is suggested to have been a ritualized landscape, and at Lejre rich deposits have been revealed at the very edge of the dead-ice area (cf. Christensen 2015; Hedeager 2011, 148-152; Szczepanik and Wadyl 2014). The forested landscape may have held cosmological connotations of the sacred grove associated with the gods, initialization and growth symbolism (Schjødt 2003, 212; Steinsland 1989, 170). Separating the contrasting topographies was a stream apparently called 'Giofn' meaning 'the Rewarding', one of several names attached to the goddess Freya. A tributary of the stream springs from the dead-ice landscape while another arm comes from the even and fertile terrain.

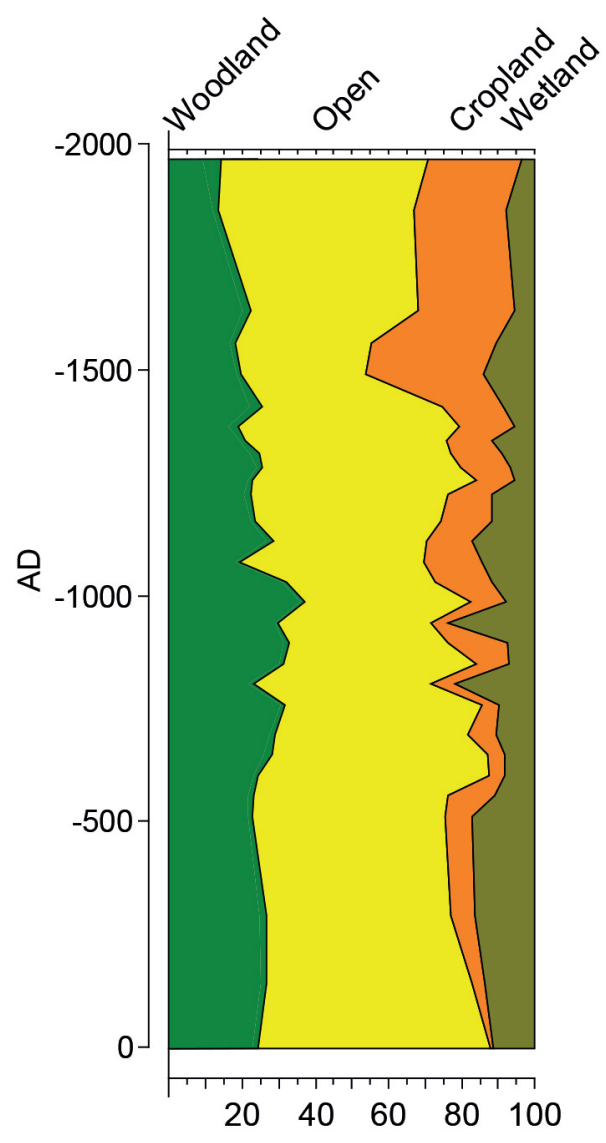

Figure 3. REVEALS modelling of pollen data from Lake Dalby shows the land use over the last 2000 years. The model compensates for differences in pollen production and dispersal between different plant taxa and translates pollen percentage data into regional vegetation composition. The diagram highlights the open grassland that dominated the landscape during the Viking period. 


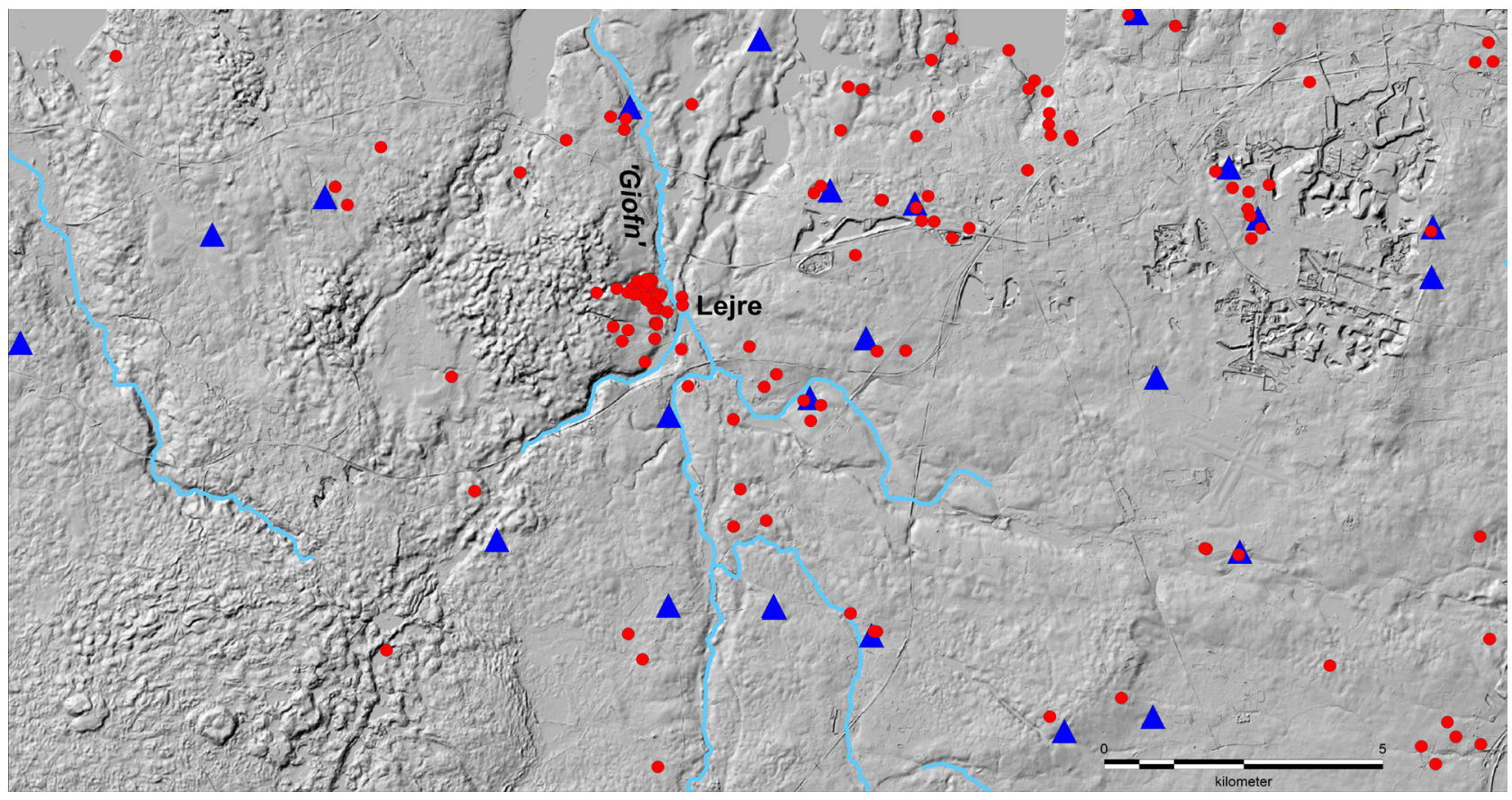

Figure 4. LIDAR map of Lejre and the surrounding area. The pronounced dead ice landscape is visible to the west while the flat, arable land is seen to the east. Dot: Viking Age find spots. Blue triangle: Place names dating from the Iron Age and Viking Age (Background map: (c) Danish Geodata Agency).

This may have been conceived as if two 'Worlds' - the sacred and the profane - were feeding a holy stream passing by Lejre on its way to the fjord. According to the archaeological evidence, the might and splendour of Lejre ended around $\mathrm{AD}$ 1000 when the hall and the three-aisled houses were no longer renewed, and at the same time the long tradition of cultic events at the site ceased. Within a century, the ritualized woodland became the scene of forest clearing and establishing of ordinary agrarian settlements.

Strøby-Toftegård is an extra-ordinary site too, situated c. $15 \mathrm{~km}$ southeast of Borgring. Even though it did not reach the status level of Lejre, excavations have revealed a magnate's residence with a series of monumental halls, long houses and pit houses combined with a remarkable find material dating the site from the $7^{\text {th }}$ century until just before AD 1000 (Beck and Schultz in prep.). The sequence of halls is not as long as at Lejre, and the halls themselves are smaller, but constructional details resemble parts of the great residential halls.

In this respect, Borgring was placed in an area situated between two extra-ordinary residential sites with central functions concerning both the sacred and the profane. Add to this the site of Ågård only $7 \mathrm{~km}$ to the west of Borgring (cf. Figure 2). Although ranking at a lower level than both Lejre and Strøby-Toftegård, Ågård is standing out in its own right both in size and continuity as well as in structure and artefacts. Furthermore, constructional details in a number of houses are pointing at a close relation between the three sites.

Lejre, Strøby-Toftegård and Ågård represent three different ranks of power of which the two superior sites lost significance or disappeared in the decenniums just before $\mathrm{AD} 1000$, most likely because of their central position in the pagan cult. The relatively high secular status of the Ågard settlement continued into the Medieval Period being the central village of the shire including a church and an aristocratic residence.

Thus, the introduction of a new ruler ideology in the late $10^{\text {th }}$ century had a profound impact on the upper pagan strata of the society, while lower strata of local aristocracy and landowners were not affected in the same way. How the unseated pagan leaders reacted is hard to say. Neither at Lejre nor at Strøby-Toftegård is any evidence suggesting a violent end to their former status. It was their pagan prominence and meaning that disappeared. It is very likely that they continued to possess their 




Figure 5. LIDAR map of Borgring (centre) in its topographical environment. The hollow road tracks are between the white arrows (Background map: () Danish Geodata Agency).

domain but apparently at a lower level of excellence and honour.

\section{Locating a Ring Fortress in the Land- scape}

Borgring sits on the sloping bank of a tunnel valley in-between two parts of an esker running parallel to the valley (Figures 2 and 5). The ring fortress is located in the middle of the nearly $1 \mathrm{~km}$ wide gap of the esker presenting itself in a very visible way. The selected building ground for the ring fortress did not meet the required needs of size and a major pre-construction modification of the building ground took place, most of all as infilling to the south and west (Jessen et al. in prep.). Therefore, it is clear that the diameter of the rampart was predetermined. Although the diameter of the different ring fortresses varies, this shows that requirements for the individual fortress were non-negotiable. Apparently, neither was the selected spot for building the fortress.

The importance of this particular position is connected to the Køge Stream valley. A thorough geo-archaeological investigation of the Køge
Stream valley has convincingly shown that the stream was not navigable for vessels larger than a dinghy during the Viking Age (Jessen et al. in prep.). Thus, the position of Borgring was not related to sailing. Instead, the possibility of crossing the stream valley was the crucial point. The issue of a dominating presence at important land based transportation corridors and the perception of the landscape have been decisive factors for the location of Borgring.

\section{Finding a Way}

Attempts to recreate a land based transportation network of the past traditionally have had a point of departure in rows of Stone Age and Bronze Age burial mounds allegedly indicating the lines of important roads (Müller 1904). This perception has been combined with Early Iron Age ramparts and Viking Age rune stones (Mathiessen 1971), settlements, fords and the nature of the terrain (Becker-Christensen 1982, 24). Lately, the GISgenerated Least-Cost-Path method to find the 'cheapest' route through a terrain has been applied (Lemm 2013, 297-307). Whatever method, the exact road is often impossible to point out, and 


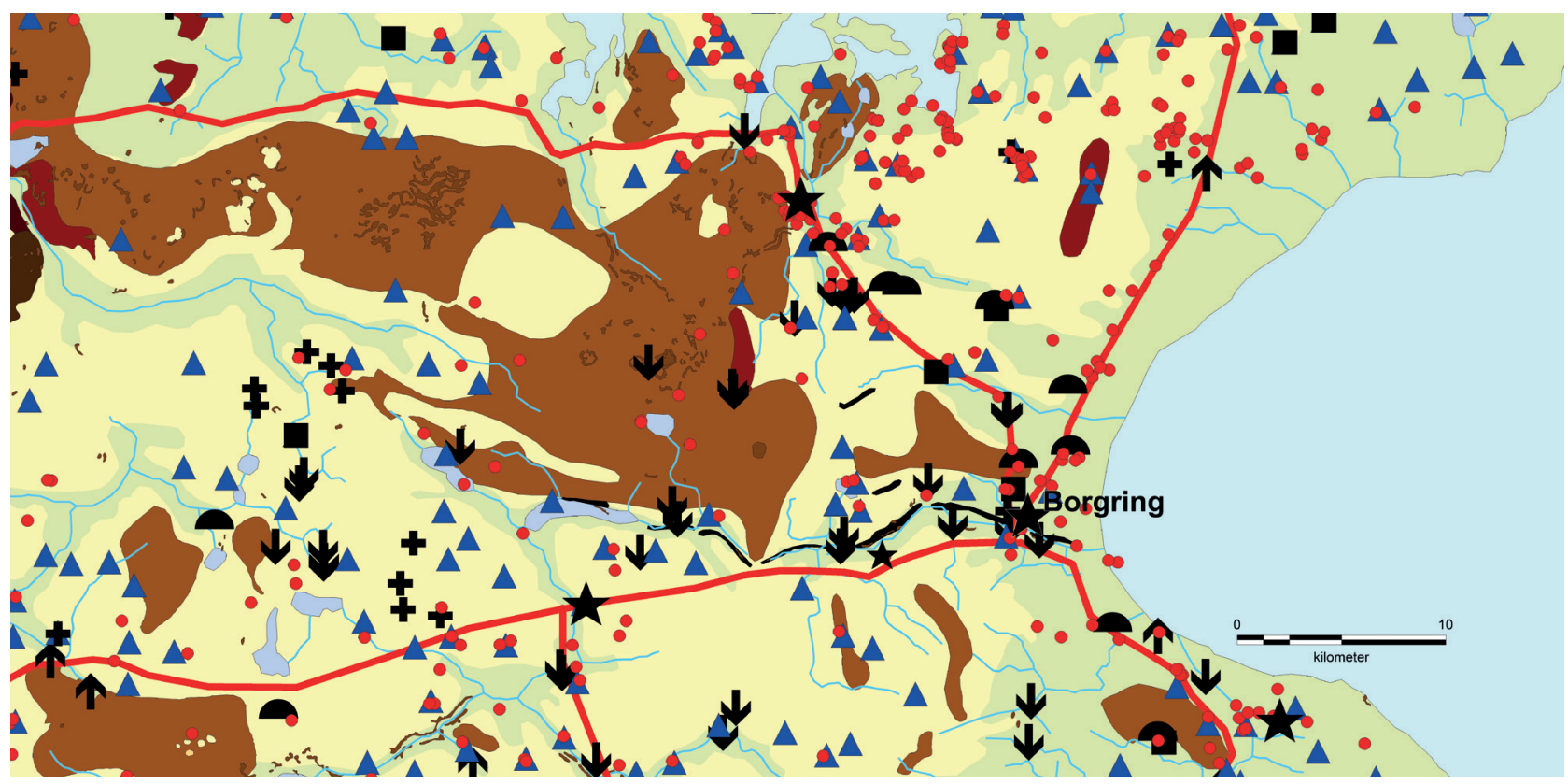

Figure 6. Map showing the principles of pointing out transport corridors (red line) in East Zealand following topography, fords, archaeological finds and place name evidence. Black cross: Place name evidence indicating a sacred place. Hemisphere: Place name including 'mound'. Square: Place name indicating centrality. Blue triangle: Place names dating from the Iron Age and Viking Age. Star: High status site. Arrow up: Documented ford. Arrow down: Ford on late $18^{\text {th }}$ and early $19^{\text {th }}$ century maps. Red dot: Viking Age site or stray find.

unless fords and hollow roads - often undated specify the track it is more likely that corridors of transport may be indicated. In other words, it is not the specific road that is appointed but a probable passage through the terrain.

During the Viking Age, Zealand had no towns as centres and therefore it is assumed that the primary routes connected different regions and magnate's residences. In this study, the suggested lines of the transport corridors follow concrete archaeological locations from villages to stray finds as well as place names dating from the first Millenium $\mathrm{AD}$ and particularly place names indicating special settlements or locations related to the upper strata of the society and the religious sphere (Figure 6). Fords are nodal points for the land-based traffic and fords - either documented archaeologically or present on cadastral maps from the late $18^{\text {th }}$ and early $19^{\text {th }}$ century - have been mapped. We cannot be sure that they have all been in use during the $10^{\text {th }}$ century but they indicate the existence of natural preconditions for fording a watercourse. Furthermore, the accessibility of the terrain has been assessed using GIS elevation maps with a $0.5 \mathrm{~m}$ contour line, GIS maps screening the steepness of the terrain exceeding 12 percent as well as digitized cadastral and topographical maps from the late $18^{\text {th }}$ and the $19^{\text {th }}$ century revealing drenched areas and wetlands of the undrained landscape.

Approximately $500 \mathrm{~m}$ to the west of Borgring, there has been a ford connecting two hollow roads. This crossing is situated where the stream valley changes from being narrow with rapidly flowing water to a wider profile with a very limited gradient of the watercourse. Considering the advantages of the terrain, it is most likely that this stretch of stream valley had been a primary point of crossing the Køge Stream since Prehistory serving as a junction for the main transport corridors. The importance of the ford at Borgring is stressed by the fact that it is nearest to the north-south transport corridor in East Zealand (Figure 7). Flanking this corridor are the 'sacred' place names Vivede ('the wood with the shrine'), Hellested ('the holy place' or 'the place owned by the man called Holy'), Godebjerg ('the hill of the god') and Salby ('the settlement with the magnate's hall/house of the gods'), and there is a concentration of place names comprising the word 'mound', maybe indicating important ancestral burials or sacred places.

Studying the topography in a wider perspective the assumption of a central ford at Borgring finds 


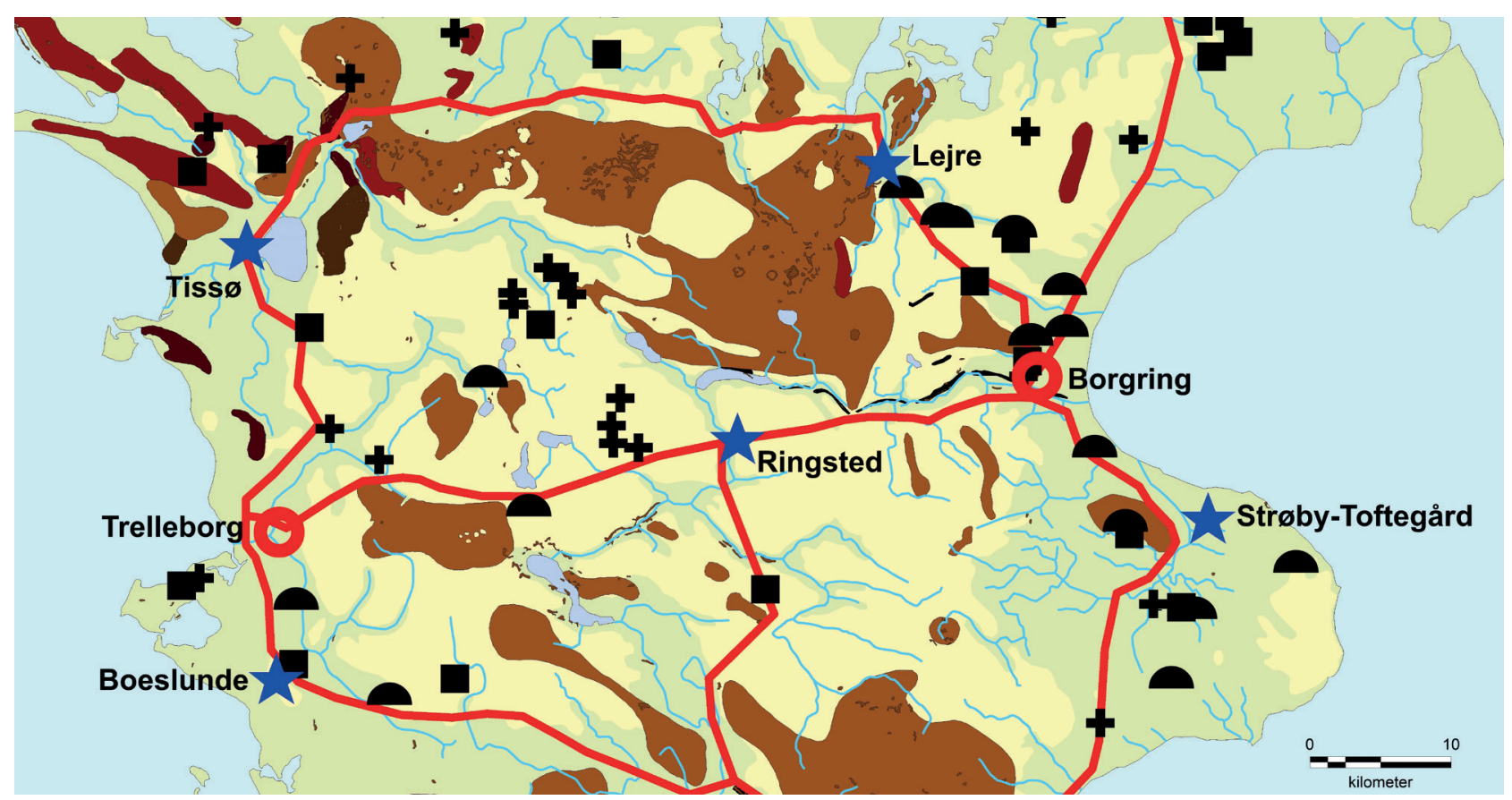

Figure 7. Suggested main transport corridors in Zealand following topography, fords, archaeological finds and place name evidence. Circle: Ring fortress. Cross: place name evidence indicating a sacred place. Hemisphere: place name including 'mound'. Square: Place name indicating centrality. Blue star: High status site including the possible ting at Ringsted.

further support. The pronounced dead-ice area of more than 350 square kilometres between the tunnel valley of Central Zealand and the fjord system of North Zealand has not offered the best of conditions for roads. The countless hillocks changing with streams, waterlogged hollows, swamps and lakes offer no easy passing. Neither archaeology nor the place name evidence indicate that the area was used for settlements during the Late Iron Age or the Viking Age. On the contrary, the place names demonstrate that the area was not settled until the $11^{\text {th }}$ century or later.

It seems evident that this terrain formed a barrier between the northeast and the northwest of Zealand, but assumingly with a transport corridor between Lejre and the residential site of Tissø ca. $45 \mathrm{~km}$ to the west passing to the north of the dead-ice area.

Considering Central Zealand it is reasonable to suggest that an east-west transport corridor south of the tunnel valley and the dead ice formation existed. For this route to connect with a north-south transport corridor in East Zealand, the ford at Borgring seems to be central in order to avoid the pronounced dead-ice terrain. At the same time, the crossing has been essential for the communication between the high status sites of East Zealand, Lejre and Strøby-Toftegård. Furthermore, the central east-west route is passing through or by the $3^{\text {rd }}$ level magnate's site, Ågård, stressing the importance of both the route and the settlement.

Taking a larger part of Zealand into consideration, it is possible to sketch a system of transportation corridors connecting specific sites of high status. In West Zealand, the two sites of Tiss $\varnothing$ and Boeslunde stand out. Tissø more or less resembles Lejre as a magnate's residence including cultic obligations through ca. 500 years (Jørgensen 2003). Approximately $30 \mathrm{~km}$ to the south, the Boeslunde settlement site consists of 11-12 separated archaeological localities within an area of ca. 38 hectares with many metal objects from the Iron Age, Viking Age and Early Medieval Period retrieved in the topsoil by metal detectorists (Nielsen 1997). Only limited trial excavations have so far shed light over the actual structure of the Boeslunde settlement area, but the amount and quality of the metal objects including more Viking Age silver treasures indicates its regional importance.

In East Zealand, Lejre and Strøby-Toftegård equal the situation of Tissø and Boeslunde. Thus, in each region there is a superior residential and cultic site connected to a site of slightly minor importance. The two superior sites are mutually connected by the northern transport corridor, and the 
central east-west route connects the regions of East and West Zealand. In the centre of the latter route, we find Ringsted. Here, the ting of Zealand was held in the early $12^{\text {th }}$ century at the latest, and both the King and the bishop of Roskilde clearly had serious interests in Ringsted in the $11^{\text {th }}$ century (Ulriksen et al. 2014, 174). Whether this position had its roots further back in time is not known. At Ringsted the central transport corridor crosses the Ringsted Stream on its way between the Great Belt and the Bay of Køge. This system of transport corridors connecting high status settlements may have been the situation for several hundred years. The importance of the network is stressed by the fact that the King added the ring fortresses Borgring in the east and Trelleborg in the west, both located on strategic points in the transportation network between the traditional pagan magnate's residences. The aim has not been to block the communication between the residential sites, farms and villages. Instead, this has been an effective way for the King to stress his power, presence and domination in a landscape including the traditional main junctions of transportation on Zealand. Considering East Zealand, the junction at Borgring may even have been perceived as a part of a ritualized main route serving the leaders of the community travelling to gatherings and religious feasts at Lejre. Even though it is difficult to substantiate specific perceptions of the landscape in a pagan society $1000-1500$ years ago, it is possible that the transport corridor between Strøby-Toftegård and Lejre is heading ever closer to the mysterious and sacred landscape embodied in the pronounced dead-ice terrain, partially following the stream originating in the fertile settled landscape until it meets the stream of Giofn coming from the 'Other World' (cf. figure 4). Following this argument, the location of Borgring is far from coincidental. On the contrary, the ring fortress dominates the important ford on the main route between the two primary pagan sites of East Zealand. It is important to notice that by the end of the $10^{\text {th }}$ century, the great halls of both Lejre and Strøby-Toftegård were no longer rebuilt, and the former importance of these high-profiled pagan locations evaporated. It may not have been Borgring in turf and timber that was so intimidating in itself, but it is a symptom of the change in fundamental ideological and religious beliefs as well as power bases in the late $10^{\text {th }}$ century. In fact, the same situation was unfolding in West Zealand, where the King's ring fortress of Trelleborg was located on the transport corridor between Boeslunde and Tissø. Thus, it is no coincidence that Trelleborg and Borgring dominated each end of the east-west transport corridor crossing Central Zealand.

\section{The topographical Situation of Iron Age Strongholds and Viking Age Ring Fort- resses: a Comparison}

In order to fully understand the idea behind the Viking Age ring fortresses it is expedient to compare their design and location with concurrent strongholds or fortifications. Regarding the identified strongholds of Viking Age Denmark, they are only few and have rarely been subject to modern excavations. They are found in different shapes and sizes and their topographical situation varies too (la Cour 1972). Some consist of a rampart of earth and sods and perhaps a moat in front of it demarcating the landside of an area that is typically bordered naturally by a stream or gorge or both to the other sides as seen at Trælborg close to Hørning, Jutland (Heijnis 2018). Others have a coherent rampart enclosing the inner space of a stronghold with access through a single gateway. This type of fortification is mostly located on hilltops or at the rim of a promontory exploiting the natural slopes on as many sides as possible. Subsequently, the terrain has a definite consequence on the outline of the earthwork bordering the inner space of the stronghold. Examples are Hochburg at Hedeby in Schleswig (Kalmring 2018) and Gamleborg in Almindingen on Bornholm (la Cour 1972, 23) (Figure 8). Differing from this topography is the position of the moat and rampart at Sankt Albert on the island of Ærø, situated on an eroding cliff facing the sea (Heijnis 2018, 40; Skaarup 2005, 248). In the flat marshlands of South Jutland is the ring-shaped but undated rampart of Trælbanke that basically resembles the location and lay-out of fortresses from the North Frisian Isles of Sylt and Föhr dating from the Viking Age (Segschneider 2009), but neither are perfectly circular or have four symmetrically positioned gates in the cardinal points of the compass. 




Figure 8. The location and topography of Gamleborg, Bornholm (LIDAR map combined with ortophoto. @ Danish Geodata Agency).

Somewhat different from these fortifications are the semi-circular ramparts with moats in front of them enclosing the Viking Age trading places Hedeby (Andersen 1998, 133), Ribe (Croix et al. 2019) and Aarhus (Jantzen 2013, 63). To begin with, these sites related to trading and seafaring did not have a fortification. It is a feature added at a point in time when needed. Thus, the location was dictated by other objectives than the fortificatory ideals.

Considering the topographical position of Borgring, the ring fortress sits on the somewhat uneven terrain of a minor promontory projecting into the stream valley at 4-10 $\mathrm{m}$ a.s.l. surrounded by higher grounds of $14 \mathrm{~m}$ to $23 \mathrm{~m}$ a.s.l. In other words, Borgring was located with a high degree of visibility in an open space at the same level or lower in the terrain than the immediate neighbourhood. As stated above the building ground was not large enough to meet the demand of the desired diameter of the rampart, so a modification of the terrain was required. Looking for an alternative place to construct a fortification would have been to build a rampart along the rim of the hilltop $500 \mathrm{~m}$ to the west overlooking the ford across the Køge Stream (cf. figure 5). The de- 
fensive values would have been at least equivalent to those of Borgring, and there could even have been more space inside the rampart. Instead, the open low-lying location was preferred.

Comparing the features of Borgring to the topographies of the other ring fortresses, there are some similarities.

Trelleborg was built with a fairly high visibility on a low-lying promontory $5.5 \mathrm{~m}$ a.s.l. between two streams, previously the scene for a Viking Age cultic site (Jørgensen 2009, 329-330; Nørlund 1948, 38-44). The surrounding terrain elevates between $8 \mathrm{~m}$ and $12.5 \mathrm{~m}$ a.s.l. As at Borgring, it has been necessary to extend the existing terrain in order to get enough space for the diameter of the rampart. Alternative defensive measures could have been a rampart across the promontory in the same way as chosen at Trælborg, near Hørning. There was an important ford at Pinemølle $1.6 \mathrm{~km}$ to the west of Trelleborg crossing the Tude Stream in a north-south direction most likely being part of the transport corridor connecting Tissø and Boeslunde (Christiansen et al. 1989; Nørlund 1948).

Nonnebakken holds most of the same characteristics as Trelleborg considering the terrain and visibility, even though the promontory is less evident. Here, it was also necessary to add soil before building the rampart in order to gain the necessary space (Runge 2018, 47). The ring fortress is situated $11 \mathrm{~m}$ a.s.l. on the lowest part of a hillside sloping from $19 \mathrm{~m}$ a.s.l. towards the Odense Stream, just opposite the budding urban site of Odense. The name 'Odense' means 'the sanctuary devoted to Odin' (Jørgensen 2008), but it is uncertain exactly where the sanctuary was located. On the northern side of the stream a settlement developed during the Viking Age and in 988, Odense became the first bishopric in Denmark outside Jutland (Runge and Henriksen 2018). The main road crossing the island of Funen from east to west is passing through Odense. One of the roads connected to it comes from the south and follows the rim of the stream valley into Odense opposite Nonnebakken and another road from the southeast enters the town crossing the stream ca. $700 \mathrm{~m}$ east of the ring fortress.

None of the ring fortresses presents itself more prominently than Aggersborg. The importance of the location is witnessed by the initial demolishing of an existing large and wealthy settlement before construction of the ring fortress on the site. From the top of the hill $600 \mathrm{~m}$ behind and $10 \mathrm{~m}$ above the ring fortress, the ground is sloping towards the Limfjord. The diameter of the rampart is twice the size of Fyrkat and the gradient of 5-6 percent inside the rampart presents the ring fortress to the spectator looking from the south. Aggersborg was a dominating feature at the important crossing of the Limfjord, and at the same time overlooking the equally important fairway shortcutting the hazardous sailing route around the Cape of Skagen.

The location of Fyrkat stands out on the narrow promontory projecting into the stream valley (Figure 9). Despite this, the promontory is actually situated lower than the surrounding sides of the stream valley (cf. Olsen and Schmidt 1977, 35, Figure 21). As at Borgring, Nonnebakken and Trelleborg, it was necessary to supply the building ground with additional levelling before constructing the rampart. Alternatively, it would have been possible to build a 'hillfort-like' rampart following the edge of the promontory secluding an area larger than the ring fortress. Previously, it has been suggested that the position of Fyrkat was chosen for its defensive/fortificatory qualifications (Olsen and Schmidt 1977, 37). Reassessing the information on Fyrkat on the background of the topographical setting of the other ring fortresses, the north-south crossing of the stream valley may have been a raison d'être. A crossing would have been possible by the reinforced but undated ford at Gammel Onsild Bro ca. $2 \mathrm{~km}$ to the west, from where the rampart of Fyrkat is visible (Figure 10). Most likely, crossing may also have been possible by means of a ford immediately east of the ring fortress. Here, a road and ford dated to the Viking Age has been excavated in the stream valley (Haue and Dobat 2013, 93). Additionally, in the outskirts of the modern town of Hobro, there are indications of hollow roads in the sloping sides of the stream valley, where it narrows in to less than $200 \mathrm{~m}$ just before it flows into the Vesterfjord. From here, Fyrkat is clearly visible. During the Medieval Period, the stream could be crossed using a bridge nearby, but it is unknown, if it existed in the $10^{\text {th }}$ century. However, the bridge emphasizes the importance of the north-south bound transport corridor going southwards to the Randers area by the River Gudenå with rich Vi- 




Figure 9. LIDAR map of Fyrkat (centre) (@ Danish Geodata Agency).

king Age burials (Nielsen et al. 1985, 1986; Pedersen 2014, Kat. 205, 210, 229, 247, 248 and 249; Stidsing 2016). To the north is Aalborg at the Limfjord, already a landing site in the Viking Age and a significant crossing point in the eastern part of the Limfjord. The important crossing point in the central part of the Limfford could be reached in the northwest at Aggersborg. On the north side of the srteam valley, a Viking Age burial place was excavated at Hørby Skoleby. Among the graves was a woman interred in a wagon body indicating a high status person. The place name of the nearby village Hørby means either 'the settlement with/by the stone heap' i.e. a hörgr or 'the settlement where flax is cultivated' (Jørgensen 2008). A few kilome- tres south of Fyrkat, the transport corridor is passing a settlement originally called Onsild meaning 'Odin's shelf/rack', presumably referring to a construction connected to the worshipping of Odin (Jørgensen 2008). In the present day village of Sønder Onsild, eight Viking Age burials have been excavated, one of which also contained a female interred in a wagon body (Roesdahl 1978). Just outside the village to the northwest is a mound called Odinshøj ('the mound of Odin'). No Viking Age burial has been found in the particular mound, but due to the oldest written form of the name, it is believed that it belongs to the Viking Age (Olsen and Schmidt 1977, 35-36.). From here, the transport corridor enters the more than 


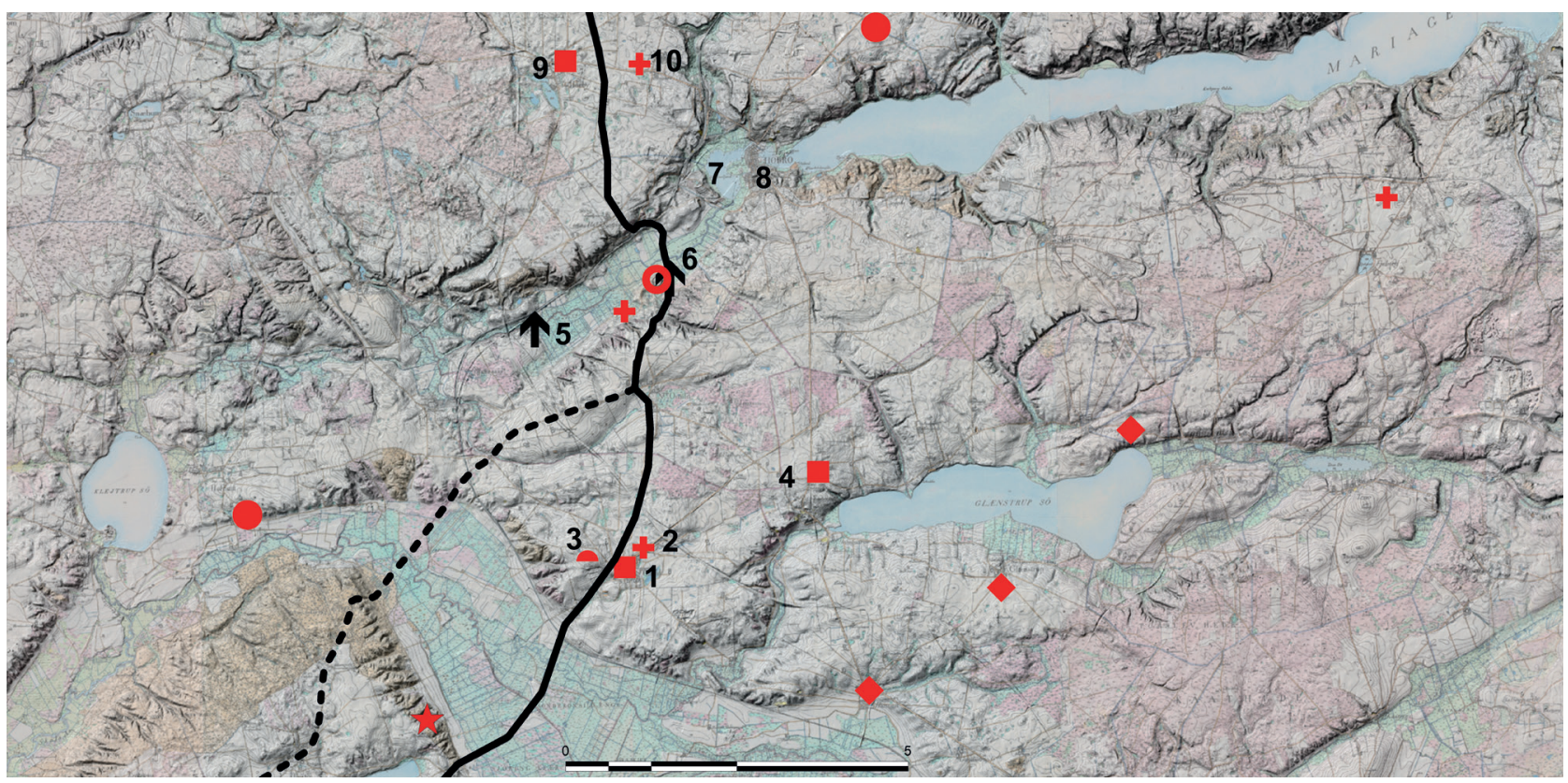

Figure 10. The topography, transport corridors and Viking Age finds around Fyrkat. 1) Sønder Onsild. 2) Burial place Sønder Onsild. 3) Odinshøj. 4) Karlby. 5) Gammel Onsild Bro. 6) Ford by Fyrkat. 7) Vesterfjord. 8) Town of Hobro. 9) Hørby. 10) Burial place Hørby Skoleby. Star: Deposited tool box. Lozenge: Rune stone. Cross: Burial. Dot: Stray find. Black line: Suggested transport corridor. Dotted black line: Suggested route by Olsen and Schmidt $(1977,38-42)$ (Background maps: (C) Danish Geodata Agency).

$1.5 \mathrm{~km}$ wide stream valley of Skals Stream through a gentle slope. Not far from the hollow road up the valley slope on the other side, a tool box was deposited in the second half of the $10^{\text {th }}$ century (Lund 2006, 325). Furthermore, rune stones have been found some kilometres to the east around the lake, Glenstrup Sø, while the place name Karlby on the north side of the lake means 'the settlement of the men' (Jørgensen 2008). Some scholars have interpreted these 'men' as members of the King's retinue (Brink 1999, 425; Dobat 2011). All these elements indicate a high status area in the centre of which the ring fortress of Fyrkat was located right on the transport corridor.

\section{To be or not to be geometric}

In the account of Borgring and its sister fortresses above, there has been an emphasis on the fact that the shape and specific diameter was chosen before the selection of the building ground and that neither was negotiable. Even though the surrounding area may have offered other topographically obvious possibilities for a fortification, the selected location was imperative. Additionally, the con- struction of the ring fortresses was well-planned, well-organized and well-executed.

Basically, there is no contradiction between this approach and a sheer fortificatory point of view. On the other hand, the preference of high visibility and a low topographical situation compared to the immediate surroundings does not increase the defensive capacity. Neither does the installation of four gates instead of just one. The extreme focus on the geometry and topography of the ring fortresses carries the mark of more than a defensive martial objective.

In Denmark, there are other large-scale structures with a geometric design ascribed to the rule of King Harald Bluetooth. In Jelling, Jutland, is the legendary burial monument of Harald's parents, King Gorm and Queen Thyra, accompanied by the rune stone of King Gorm commemorating his wife, and Harald's rune stone commemorating his parents and the deeds of Harald himself. Recently, excavations have revealed a massive palisade of oak with four ca. $360 \mathrm{~m}$ long sides forming a rhombus encapsulating a ca. $360 \mathrm{~m}$ long ship shaped stone setting and two large mounds (Holst et al. 2012). Dendrochronology indicates that the rhombus was built between AD 958 and 
985, most likely around the year AD 968 (Jessen et al. 2014, 14).

At Ravning Enge, some $10 \mathrm{~km}$ to the southwest of Jelling, a ca. $760 \mathrm{~m}$ long oak bridge is another impressive structure from the era of Harald Bluetooth (Jørgensen 1997). The bridge was ca. $5 \mathrm{~m}$ wide and formed a straight line across the Vejle Stream valley. Timbers are dated to AD 979 or 980 by dendrochronology. At both ends of the bridge, heavily worn hollow roads are making their way up the steep slopes of the valley. Excavations have not revealed traces of an earlier ford, even though the Roman Iron Age fortification of Troldborg Ring at the top of the northern rim of the stream valley holds a strategic position for controlling a crossing at this point. Instead, it has been suggested that the primary ford in the area was located at Kolborg some $2 \mathrm{~km}$ to the west of the Ravning Enge bridge (Jørgensen 1997, 83). From time to time, the Kolborg ford was reinforced with stones, branches and timbers and dendrochronology indicates more building phases during the $3^{\text {rd }}-6^{\text {th }}$ centuries $A D$, the $9^{\text {th }}-10^{\text {th }}$ centuries $A D$ and in the $14^{\text {th }}$ century AD (Deichmann and Lindblom 2011). The hollow roads leading to the Kolborg ford are not as worn as at the Ravning Enge bridge, but this can be due to differences in preservation.
Speaking of roads, it is conspicuous that the primary ancient transport corridor of Jutland, Hærvejen (in Medieval terms 'the public road'), is passing by Jelling ca. $2.5 \mathrm{~km}$ to the west and from there makes a noticeable turn to a westerly route in order to avoid the Vejle Stream valley (Mathiessen 1971, 49) (Figure 11). Hærvejen as a subject is traceable in the written records from the Medieval Period but it is assumed that it has its roots in Prehistory. Burial mounds tend to indicate the line of Hærvejen in some areas of Jutland including the Jelling area, but it is also clear that the direction of the road could change through time from the Bronze Age to the Viking Age (Becker-Christensen 1982, 20 and Figure 72). If Hærvejen had its course across the Vejle Stream valley during the Viking Age it may have been at the Kolborg ford or at Ravning Enge.

It has been suggested that the Ravning Enge bridge was constructed in order to secure the supply line to the border at Danevirke, where tensions were building up between the Danish king and the East-Frankish King Otto II in the 970ties (Jørgensen 1997, 86). If supply lines from Central East Jutland were of the essence in relation to the situation at Danevirke a hundred kilometres away it is difficult not to consider Hærvejen as fit for the task. Even though crossing the Vejle Stream valley

Figure 11. The topography around the Ravning Enge bridge. 1) Jelling. 2) Ravning Enge bridge. 3) The Kolborg ford. 4) Vejle Fjord. 5) Grejs Stream valley. Black line: Hærvejen. Dotted line: the probable route using the Ravning Enge bridge (Background map: (C) Danish Geodata Agency).

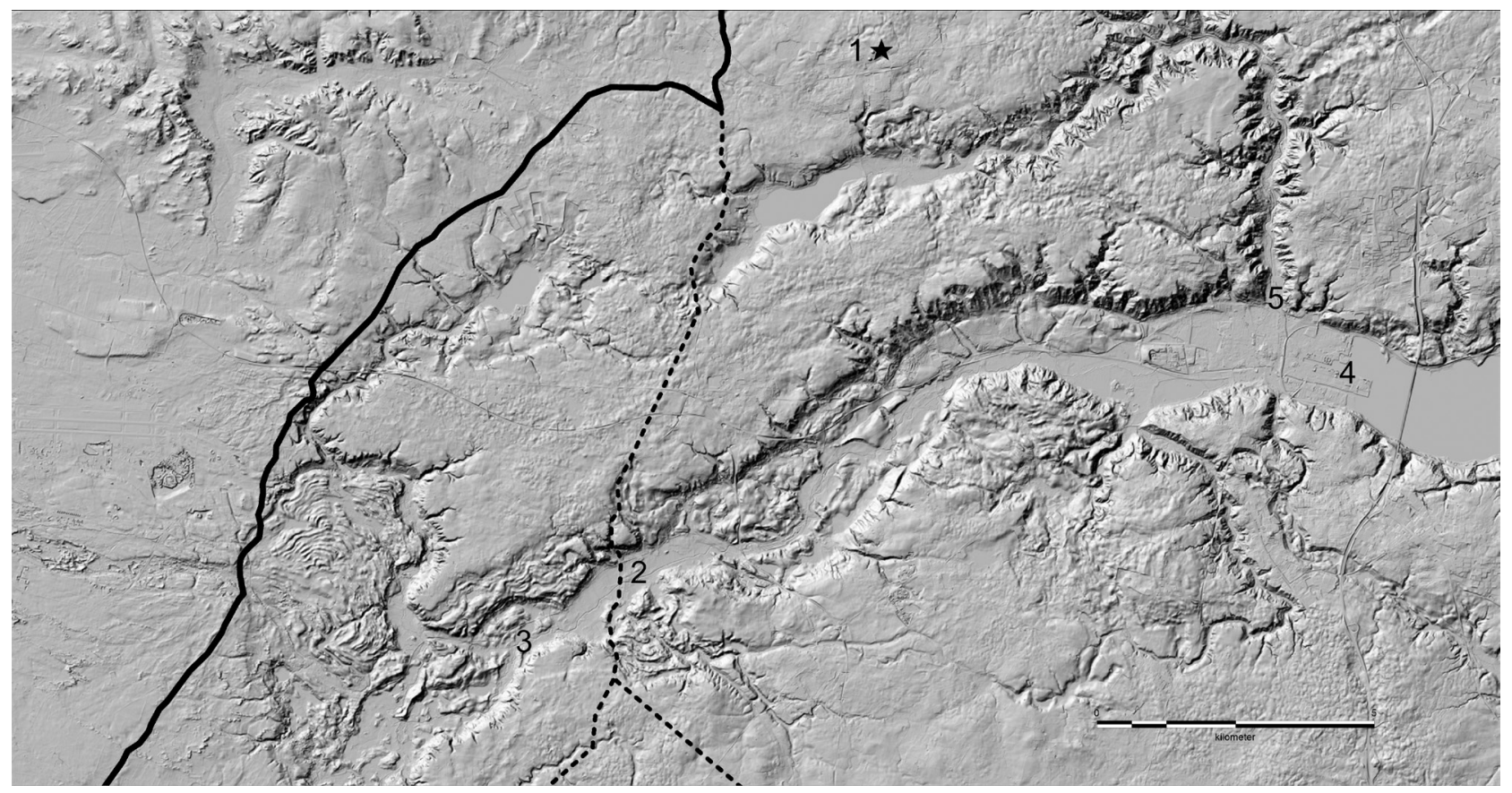


is a short cut it is no more than $5-10 \mathrm{~km}$ gained and in that case, the ford at Kolborg offered the necessary facilities.

Instead, the Ravning Enge bridge may have invited the transport between the trading site of Aarhus and the south-eastern part of Jutland, and travellers crossing from Funen to Jutland going north may have followed a transport corridor passing Erritsø (cf. below) to Ravning Enge and circumventing the extremely steep sided valley of Grejs Stream between the Vejle Stream valley and Jelling (cf. Figure 11). The time of building of the Ravning Enge bridge coincides with the existence of the geometrical ring fortresses and so does the meticulous precision and skill in the robust construction. Likely, the purpose was to impress people travelling between locations of importance in East Jutland and the link to the rhombus palisading the royal graves of King Harald's parents is evident.

Also at the Dannevirke fortification, Harald Bluetooth has put his mark. The fortification line dates back to the Migration Period at the least, and has been expanded several times (Tummuscheit and Witte 2018). In the $10^{\text {th }}$ century it consisted of a sequence of ramparts $17 \mathrm{~km}$ long - most of them interconnected - that practically functioned as the border line across the root of the Jutland peninsula (Andersen et al. 1976; Andersen 1998). The ramparts of Dannevirke take advantage of the fortificatory lines of the terrain in order to secure the passageways between wetlands, lakes and streams.
Thus, the lines of the ramparts are organic and modelled by the terrain in which they are implemented. In contrast to this, is Kovirke, a ca. $6.5 \mathrm{~km}$ long rampart and moat forming a completely straight line between the wetlands along the Rheide Stream and the innermost part of the fjord Schlei, Selk Nor (Figure 12). The ca. $7 \mathrm{~m}$ wide rampart was built of soil dug up from the moat with a V-shaped cross section in front of it and the front of the rampart was clad with a timber palisade. A $4 \mathrm{~m}$ wide gateway with two rows of posts as walls has been excavated. The dating of Kovirke to the $10^{\text {th }}$ century rests on ${ }^{14} \mathrm{C}$-dated charcoal found in the postholes from the palisade, but it has been suggested that the rampart was built in the last quarter of the $10^{\text {th }}$ century because of constructional similarities with the ring fortresses (Andersen 1998, 167; Erlenkeuser 1998, 193-194; Dobat 2008, 42). In accordance with the other structures ascribed to Harald Bluetooth is in particular the strict geometric design and the V-shaped moat. Also the construction of the palisade and gateway resembles that of the ring fortresses. Furthermore, the selected locality for the geometric figure of Kovirke is in front of the main system of ramparts of the border zone built through centuries. Indeed, it follows the intention of exclusiveness and visibility, where people travel - and where the forces of the East-Frankish King may have mustered before an attack.

Denmark holds other monumental constructions from the Viking Age, which are definitely spectacular but do not have an explicit focus on

Figure 12. The complete fortification line of Dannevirke. Kovirke is the straight long line to the south. Map by Jørgen Andersen, Museum Sønderjylland (after Tummuscheit and Witte 2018, Figure 1)

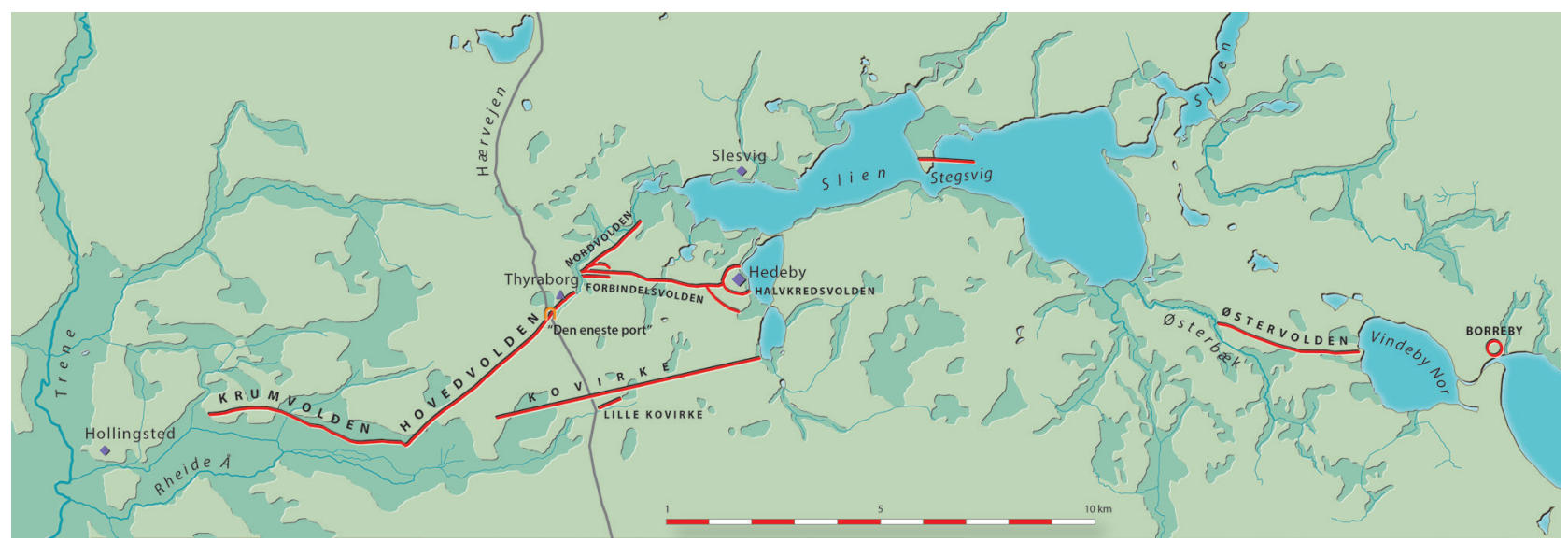


geometry and symmetry. Examples of Viking Age fortifications not belonging to the geometrical ring fortresses have been mentioned above and in short they take different shapes and are situated in varying topographies. Aristocratic sites with substantial palisades are known from both Zealand and Jutland, but it is debated, whether they are to be understood as defensive measures or if they are 'just' exclusive to the surroundings.

At Lejre, a nearly $1 \mathrm{~m}$ deep trench for a palisade is framing an area of ca. 2.6 hectares including the hall and other buildings dating from the $8^{\text {th }}$ century (Christensen 2015, 76 and 85). The shape of the palisade was four-sided but far from geometrical.

At Tissø the residential area of 1 hectare in the $6^{\text {th }}$ century to 2.5 hectares in the $10^{\text {th }}-11^{\text {th }}$ century was fenced from the beginning to the end, but there was neither a fortificatory motive nor was there any desire for geometry (Jørgensen 2009, 338).

The same pattern of late Viking Age magnate's residences enclosed by fences but without a geometrical design are known from Lisbjerg (Jeppesen and Madsen 1990), Vorbasse (Hvass 1980) and Gammel Hviding (Feveile 2014, 76), all in Jutland.

In contrast to this, is the recently excavated magnate's residence at Erritsø on the east coast of Jutland. Excavation has revealed a square of 110 by $110 \mathrm{~m}$ defined by a palisade with a $1.6 \mathrm{~m}$ deep V-shaped moat in front of it (Ravn et al. 2019). There are no preserved traces of a rampart, but it is assumed that at least the dug-up fill from the moat has been placed behind the palisade. Inside the square is a large $34 \mathrm{~m}$ by $12 \mathrm{~m}$ main building connected to a fenced-in special area including a smaller house resembling the situation at Lejre and Tissø. ${ }^{14} \mathrm{C}$-datings tend to place Erritsø in the $8^{\text {th }}$ $9^{\text {th }}$ century. Obviously this is older than the reign of Harald Bluetooth, and it makes it even more striking that Erritsø holds at least two characteristic features of late $10^{\text {th }}$ century royal construction work: the palisade forms a geometric square and the moat has a V-shaped cross section just like Kovirke and the ring fortresses. Add to this the prominent and visible location in the terrain overlooking both an important fairway of the Little Belt and an equally important crossing of the same fairway between Funen and Jutland. Separated in time, though, Erritsø stands alone and premature in the Early Viking Age.

Summarizing the large-scale constructions of the $10^{\text {th }}$ century $\mathrm{AD}$ and comparing them to corresponding structures from the First Millennium $\mathrm{AD}$, it is clear that a group characterized by a geometrical design dated between AD 968 and 981 stands out. Each structure in this group exudes premeditation, organization and skilful execution and they are all situated at strategically critical spots in the communication system of roads, fairways and crossings. Together they indicate a comprehensive plan covering the Kingdom of Denmark aiming at executing the sensation of royal presence in a prominent and dominating way. On Zealand, Trelleborg and Borgring were located on main routes. On Funen, Nonnebakken both dominated the communication across the island, the pagan cultic site and the budding town of Odense. In Jutland, Aggersborg was overlooking the crossing and the fairway of the Limfjord, while Fyrkat sat on the main road in a high-status loaded area between important locations like Aarhus and Aalborg.

The monuments in question are constructed within a relatively short span of time -10 to 15 years - and they all lost their significance shortly after they were built. Among the ring fortresses Aggersborg, Fyrkat and Borgring seem to have only been partly finished (Ljungkvist et al. in prep., Olsen and Schmidt 1977, 76; Ulriksen 1990), and Fyrkat, Trelleborg and Borgring all bear witness to partial damage by fire (Ljungkvist et al. in prep.; Nørlund 1948; Olsen and Schmidt 1977), and at least parts of the palisade at Jelling were burned too (Jessen et al. 2004, 19). None of the fortresses were ever rebuilt, Kovirke was never repaired (Andersen 1998,168$)$ and there are indications that the Ravning Enge bridge may have lasted less than 5 years (Jørgensen 1997, 82). On the basis of the existing evidence, it is not possible to verify whether the simultaneous collapses coincided with the violent death of Harald Bluetooth in AD 986 or 987. However, if the observation concerning the duration of the Ravning Enge bridge is accurate the fall of king and bridge is overlapping. It is therefore feasible that there was a direct link between the death of Harald Bluetooth and the collapse of the symbols of the newly established power structure. 
The only signs of repair and secondary building activity are found at Trelleborg, an incident dated to AD 981 (Nielsen 1990). After AD 986/987 it seems like no one had much interest in maintaining the structures. The vision behind them obviously lost its meaning. Inside the rampart and in the gateways of Trelleborg and to some extent at Borgring, there is evidence of a short-lived 'afterlife' in the $11^{\text {th }}$ century that clearly differs from the original design and idea (Christensen et al. in prep.; Ljungkvist et al. in prep.; Nørlund 1948).

\section{A Conclusion and a Theory}

The hypothesis of this study is that Borgring was built, not merely as a military defensive controlpost/ fortress, but specifically as a symbol of royal power with the purpose of applying a significant impact on the society in the region. The analysis of the aristocratic sites around Borgring shows that Lejre, the residential manor of a king and a central pagan cult site for ca. 500 years, ceased to exist around AD 1000. Within the same narrow time frame the magnate's residence of Strøby-Toftegård met the same destiny. Even though we cannot produce exact archaeological or dendrochronological dating of the downfall of the two important pagan locations, the evidence strongly indicates a connection between their fate and the introduction of Borgring and a stronger and Christian royal power.

Borgring itself could not have been constructed at a more central location in late $10^{\text {th }}$ century Eastern Zealand. Here, the extra-ordinary design was at display on a scene, which had been prepared carefully beforehand by moving more than 1900 cubic metres of soil to the site.

The visibility, the excellence and the dominance of main transportation corridors tie the idea of the ring fortresses together. Other Viking Age fortifications like Gamleborg, Trælborg and also the Iron Age rampart Troldborg Ring seem to have been constructed at important roads too, but their way of using the topography differs from the ring fortresses by holding hilltops. The fortified trading places are focused on navigability and their defence works are secondary and therefore conditioned by the terrain in a different way than the 'hillforts'. The linear structures of Kovirke and the Ravning
Enge bridge and the rhombus of Jelling share the constructional stringency and topographical significance with the ring fortresses and they all belong to the same decades of the reign of Harald Bluetooth. Kovirke and the Ravning Enge bridge also share the fact that their functional capacities were already taken care of or could have been achieved in an easier and even better way in the close vicinity. It is equally important to note that after the death of Harald Bluetooth these specific monuments were abandoned.

These observations witness a building programme instituted by an unprecedented geometrical design mirroring a vision of the King in order to put his explicit mark on his realm. The constructions clearly differ from the traditional structures and magnate's residences with roots in the Iron Age society and point towards a new era. For King Harald Bluetooth the initiation must have been his baptizing in AD 963 (Gelting 2010, 106).

Why Harald turned away from the Pantheon of Norse mythology and received baptism at this point in time is still debated. Faith is a possibility, of course, but there is no reason to doubt that he has observed ideological, political and maybe even economic advantages in the Christian order of society (cf. Gelting 2010, 123; Randsborg 1980, 21-22; Sawyer 1982, 139; Steinsland 2000, 95, 147). It is also probable that during the two decades between Harald's baptism and his death he attempted to implement the different elements of the new order by means of a firm power base throughout his realm. His progress and rate of success is difficult to estimate. The sentence on the rune stone of Jelling '.. won the whole Denmark for himself...' (translation from Holst et al. 2012, 479) may imply that Harald's conversion had support from chieftains and magnates all over his kingdom. There are no written accounts nor archaeological evidence suggesting turmoil, uproar or skirmishes because of the conversion and the deconstruction of the central pagan site of Lejre took place around $\mathrm{AD} 1000$ in a way that has left no traces of violence. On the other hand, the subjection could have been forced upon reluctant parties without burning down the settlements.

In an atmosphere that may have been more delicate, than we can detect today, King Harald Bluetooth instigated his ambitious building pro- 
gramme. The motive may have been to stress that the conversion combined with the ideological and political alterations included his subjects.

Around AD 968, Harald apparently refurbished the burial monument of his parents by building the rhombus and the associated houses. The rune stone promoting Harald's deeds may have been part of this initiative. In reality, Harald made use of an important trick to inspire confidence in his vision of his future reign. The pagan mound, where it is assumed that King Gorm was interred, was a symbol of power, a sign of tradition, of trust and the continuation of life (Steinsland 2000, 157). By showing respect for the mound, Harald secured a basis in the pagan tradition but at the same time he was adding a symbolic construction around them pointing in the direction of a new order - his new Christian order. Within a few years, the construction of the ring fortresses began. Fyrkat holds the oldest dating indicating the mid-970ties, but there is no convincing evidence revealing, which fortress was the first one, or if they were built more or less at the same time. Trelleborg has a secondary building phase in $\mathrm{AD}$ 981, but we do not know, when it was initially constructed and that also concerns Aggersborg, Nonnebakken and Borgring. We consider that all of the ring fortresses were built between 968 and 986, as were the rhombus of Jelling, the Ravning Enge bridge and Kovirke. All of the structures were monumental, and even though most of them have the expression of fortifications, they did not take the most advantageous fortificatory positions in the topography. Instead, they held prominent locations where they were visible to travellers on important routes. Furthermore, their geometric shapes stood out and were difficult to ignore. They would have signalled the presence of the King and his new order even though he was not there in person.

\section{Final remarks}

Did it work? 'Yes' is the short answer considering the assumed situation on Zealand, but it was probably not until the time of King Harald Bluetooth's grandson, King Knud the Great, that all aspects of 'the new order' were implemented and accepted by the subjects. To Harald, the building programme may even have caused the rebellion that he met in the mid-980ties. Most likely, the King had asked his chieftains to provide the necessary turfs, soil, timbers and men for the construction work, and maybe he went too far in his demands. From written accounts of a later date there are indications that King Harald enforced too heavy burdens on the commoners resulting in the rebellion led by the King's son, Sven Forkbeard. The type of burden is obscure, but the building programme may have been part of it.

After Harald was killed, there is no evidence of use or maintenance of the structures, probably because they had no indispensable function, and because they signalled all that was wrong with King Harald Bluetooth's reign in the mid 980ties. In this light, we may perceive the burning of at least parts of the palisade in Jelling and the partial fires in the gateways of Fyrkat, Trelleborg and Borgring as symbolic or ritualized destructive measures in the wake of Harald's death.

One may object that the ring fortresses had a military purpose. The constructions fulfil such a task and their topographical setting do have defensive benefits, but putting the evidence together another explanation materializes and stresses the fact that the emblematic values of the structures of King Harald Bluetooth are not to be underestimated.

\section{Acknowledgements}

The Borgring Project 2016-2018 was generously funded by A.P. Møller og Hustru Chastine Mc-Kinney Møllers Fond til almene Formaal and the Municipality of Køge.

The authors would like to thank Mads Runge, Ph.D., Odense City Museums, for his valuable comments on a draft of the manuscript. Thanks also to the peer reviewers whose questions and remarks have improved the result. 


\section{Bibliography}

Andersen, H.H., 1988. Ringborgene og den militære begivenhedshistorie. Kuml, 1986, 7-19.

Andersen, H.H., 1998. Danevirke og Kovirke. Arkeologiske undersøgelser 1861-1993. Højbjerg: Moesgård Museums skrifter. Jysk Arkæologisk Selskab.

Andersen, H.H., Madsen, H.J. and Voss, O., 1976. Danevirke. Højbjerg: Jysk Arkæologisk Selskabs Skrifter, bind. XIII.

Beck, A.S. and Schultz, M.K., eds., in prep. Strøby Toftegard - the excavations 1995-2013. The National Museum: PNM Series.

Becker-Christensen, H., 1982. Harvejen i Sønderjylland - et vejhistorisk studie. Fra Kongeåen til Danevirke. Institut for Grænseregionsforskning.

Brink, S., 1999. 'Social order in the early Scandinavian landscape'. In: C. Fabech and J. Ringtved, eds, Settlement and Landscape. Proceedings of a conference in Arhus, Denmark, May 4-7 1998. Højbjerg: Jysk Arkæologisk Selskab, 423-437.

Christensen, J., Daly, A., Henriksen, P.S., Holm, N., Jessen, C., Jørgensen, S., Olesen, L., Olsen, J.,Schultz, M.K., Sindbæk, S.M. and Ulriksen, J., in prep. Borgring. Uncovering the strategy for a Viking-age ring fortress in Denmark.

Christensen, T., 2007. 'A New Round of Excavations at Lejre (to 2005)'. In: Niles, J.D. Beowulf and Lejre. Medieval and Renaissance Texts and Studies, Vol. 323. Tempe, Arizona: Arizona Centre for Medieval and Renaissance Studies, 109-126. https://doi.org/10.1179/eja.2011.14.1-2.336

Christensen, T., 2015. Lejre bag myten. De arkaologiske udgravninger. Højbjerg: Jysk Arkæologisk Selskab. https://doi.org/10.1086/689705

Christiansen, T.E., Foged, N., Jørgensen, S. and Petersen, K.S., 1989. Trelleborg og Pine Mølle. Aarbøger for Nordisk Oldkyndighed og Historie 1989, 7-98.

Croix, S., Gundersen, O.E., Kristiansen, S.M., Olsen, J., Sindbæk, S.M. and Søvsø, M., 2019. Dating earthwork fortifications: Integrating five dating methods in Viking age Ribe, Denmark. Journal of Archaeological Science: Reports 26. https://doi.org/10.1016/j.jasrep.2019.101906

la Cour, V., 1972. Danske borganleg til midten af trettende århundrede. Copenhagen: The National Museum.

Dobat, A.S., 2008. Danevirke Revisited: An Investigation into Military and Socio-political Organisation in South Scandinavia (c AD 700 to 1100). Medieval Archaeology, 52, 28-67.

https://doi.org/10.1179/174581708x335431

Dobat, A.S., 2011. 'Mapping social order: Place-names containing rink or karl and the development of political administration in the 10th century South Scandinavia'. In: L.E. Christensen and B. Jørgensen, eds. Navnemiljøer og samfund i jernalder og vikingetid. Beretning fra 38. NORNA-symposium. NORNA-rapporter 86, 2010. Copenhagen, 41-73. 
Deichmann, P.C.M. and Lindblom, C., 2011. Beretning VKH 7284 Vejle Å. Unpublished report. VejleMuseerne.

Erlenkeuser, H., 1998. 'Neue C14-Datierungen zum Danewerk, Schleswig-Holstein'. In: H.H. Andersen, ed. Danevirke og Kovirke. Arkaologiske undersøgelser 1861-1993. Århus: Aarhus University Press, 189-201.

Feveile, C., 2014. 'At the geestland edge southwest of Ribe: On the track of a centre of wealth during the $1^{\text {st }}$ millennium AD'. In: E. Stidsing, K.H. Nielsen and R. Fiedel, eds. Wealth and complexity. Economically specialised sites in Late Iron Age Denmark. Aarhus University Press, 73-89.

Gelting, M., 2010. Poppo's Ordeal: Courtier Bishops and the Success of Christianization at the Turn of the First Millennium. Viking and medieval Scandinavia. Volume 6, 101-133.

https://doi.org/10.1484/j.vms.1.102138

Haue, N. and Dobat, A.S., 2013. 'Undersøgelserne ved Fyrkat'. In: A.S. Dobat, ed. Kongens Borge. Rapport over undersøgelserne 2007-2010. Højberg: Jysk Arkæologisk Selskab, 71-112.

Hedeager. L., 2011. Iron Age Myth and Materiality. An Archaeology of Scandinavia AD 400-1000. London/New York. https://doi.org/10.4324/9780203829714

Heijnis, A., 2018. 'Early Viking Camps in Scandinavia and abroad'. In: J. Hansen and M. Bruus eds. The Fortified Viking Age. The 36th Interdisciplinary Viking Age Seminar, Odense 2017, 35-43. https://doi.org/10.4324/9781315548197-1

Holst, M.K., Jensen, M.D., Andersen, S.W. and Pedersen, A., 2012. The Late Viking-Age Royal Constructions at Jelling, central Jutland, Denmark. Recent investigations and a suggestion for an interpretative revision. Prähistorische Zeitschrift 2012:87(2), 474-504.

https://doi.org/10.1515/pz-2012-0022

Hvass, S., 1980. Vorbasse. The Viking-age Settlement at Vorbasse, Central Jutland. Acta Archaeologica, vol. 50 - 1979, 137-172.

Jantzen, C., 2013. Middelalderbyen Aarhus. Tarm.

Jeppesen, J. and Madsen, H.J., 1990. Stormandsgård og kirke i Lisbjerg. Kuml, 1988-89, 289-310.

Jessen, C., Henriksen, P.S., Hald, M.M. and Ulriksen, J., in prep. The lost landscape of Borgring: geoarchaeological investigations into the navigation to, and location of, the Danish Viking Age ring fortress.

Jessen, M.D., Holst, M.K., Lindblom, C., Bonde, N. and Pedersen, A., 2014. A Palisade Fit for a King: Ideal Architecture in King Harald Bluetooth's Jelling. Norwegian Archaeological Review, 1-23. https://doi.org/10.1080/00293652.2014.921239

Jørgensen, B., 2008. Danske stednavne. Gyldendal.

Jørgensen, L., 2003. 'Manor and Market at Lake Tissø in the Sixth to Eleventh Centuries: The Danish 'Productive' Sites'. In: T. Pestell \& K. Ulmschneider, eds. Markets in Early Medieval Europe. Trading 
and 'Productive Sites, 650-850. Windgather Press, 175-207.

https://doi.org/10.1179/eja.2004.7.2.206

Jørgensen, L., 2009. 'Pre-Christian cult at aristocratic residences and settlement complexes in southern Scandinavia in the $3^{\text {rd }}-10^{\text {th }}$ centuries AD'. In: U. von Freeden, H. Friesinger \& E. Wamers, eds. Glaube, Kult und Herrschaft. Phänomene des Religiösen im 1. Jahrtausend n. Chr. in Mittel-und Nordeuropa. Akten des 59. Internationalen Sachsensymposions und der Grundprobleme der frühgeschichtlichen Entwicklung im Mitteldonauraum. Kolloquien zur Vor- und Frühgeschichte Band 12. Bonn, 329-354. DOI: https://doi.org/10.1163/9789004293885_022

Jørgensen, M.S., 1997: Vikingetidsbroen i Ravning Enge - nye undersøgelser. Nationalmuseets Arbejdsmark 1997, 74-87.

Kalmring, S., 2018. Hedeby Hochburg - Theories, State of Research and Dating. Offa 71/72, 2014/2015, 241-291.

Lemm ,T., 2013. Die frühmittelalterlichen Ringwälle im westlichen und mittleren Holstein. Schriften des Archäologischen Landesmuseums 11. Band 1. Neumünster.

Ljungkvist, E., Thomsen, B., Sindbæk, S.M., Christensen, J., Holm, N., Schultz, M. and Ulriksen, J., in prep. Coldest case of all - fire investigation at the Viking Age ring fortress of Borgring, Denmark.

Lund, J. 2006: Vikingetidens værktøjskister i landskab og mytologi. Fornvännen 101, 2006, 323-341.

Mathiessen, H., 1971. Harvejen. En Tusindårig Vej fra Viborg til Danevirke. En historisk-topografisk Studie. (1930.) Gyldendal.

Mortensen, M.F., Pløsch-Danielsen, L., Stockholm, J.R. Nielsen, A.B., Olsen, J. and Schultz, M.K., in prep. A. 11.000 years of vegetation dynamic and environmental changes base on pollen and macrofossil data from Lake Dalby, Southeast Denmark.

Mortensen, M.F., Baittinger, C., Christensen, J., Nielsen, A.B., Nielsen, S., Pihl ,A., Prøsch-Danielsen, L., Ravn, M., Sindbæk, S.M. and Ulriksen J., in prep. B. Turfs and timbers - sourcing the materials for a Viking fortress.

Müller, S., 1904. Vej og Bygd i Sten- og Bronzealderen. Aarbøger for nordisk Oldkyndighed og Historie 1904, 1-64.

Nielsen, B.H., Kristensen, I.K. and Stidsing, E., 1985: Vikingetidsgravpladsen Kjølvejen. Undersøgelser i 1985. Historisk Aarbog fra Randers Amt 79, 1985, 5-14.

Nielsen, B.H., Kristensen, I.K. and Stidsing, E., 1986: Kjølvejen - en vikingetidsgravplads ved Over Hornbæk. Undersøgelser i 1985. Historisk Aarbog fra Randers Amt 80, 1986, 5-16.

Nielsen, H., 1997. 'Et regionalt rigdomscenter i Sydvestsjælland'. In: J. Callmer and E. Rosengren, eds. "...gik Grendel att söka det höga huset...". Arkeologiska källor till aristokratiska miljöer i Skandinavien under yngre järnålder. Rapport från ett seminarium i Falkenberg 16-17 november 1995. Hallands Länsmuseers Skriftserie No 9/GOTARC C. Arkeologiska Skrifter No 17. Halmstad, 55-70. 
Nielsen, L.C., 1990. Trelleborg. Aarbøger for nordisk Oldkyndighed og Historie 1990, 105-178.

Nørlund, P., 1948: Trelleborg. Nordiske Fortidsminder IV:1. Copenhagen.

Olsen, O. and Schmidt, H., 1977. Fyrkat. En jysk vikingeborg. I. Borgen og bebyggelsen. Copenhagen.

Pedersen, A., 2014. Dead Warriors in Living Memory. A Study of Weapon and Equestrian Burials in Viking-Age Denmark, AD 800-1000. Publications from the National Museum. Studies in Archaeology and History Vol. 20:1 (1-2). University Press of Southern Denmark.

Randsborg, K., 1980. The Viking Age in Denmark. The Formation of a State. London: Duckworth.

Ravn, M., Juel, C., Lindblom, C. and Pedersen, A., 2019. 'Erritsø - new investigations of an aristocratic, early Viking Age manor in Western Denmark, c. 700-850 AD'. In: R. Annaert, T. Bellens, P. Deckers, F. Theuws, D. Tys, R. van Dierendonck, L. van Impe, J Veeckman and L. Verslype, eds. Early medieval waterscapes. Risks and opportunities for (im)material cultural exchange. Neue Studien zur Sachsenforschung. Band 8. Published by the Braunschweigisches Landesmuseum and the Agentur für das Kulturerbe Flanderns. Braunschweig, 37-45.

Roesdahl, E., 1978. Otte vikingetidsgrave i Sdr. Onsild. Aarbøger for nordisk Oldkyndighed og Historie $1976,22-51$.

Roesdahl, E. and Sindbæk, S.M., 2014. 'The purpose of the fortress'. In: E. Roesdahl, S.M. Sindbæk, A. Pedersen and D.M. Wilson, eds. Aggersborg: The Viking-Age Settlement and Fortress. Højbjerg: Jutland Archaeological Society. https://doi.org/10.1080/00665983.2015.1112671

Runge, M., 2018: 'New archaeological investigations at Nonnebakken, a Viking Age fortress in Odense'. In: J. Hansen and M. Bruus, eds.: The Fortified Viking Age. The $36^{\text {th }}$ Interdisciplinary Viking Age Seminar, Odense 2017, 44-59. https://doi.org/10.2307/j.ctv4t7z9h.8

Runge, M. and Henriksen, M.B., 2018. The origins of Odense - new aspects of early urbanisation in southern Scandinavia. Danish Journal of Archaeology. https://doi.org/10.1080/21662282.2018.1475 891

Sawyer, P.H., 1982. Kings and Vikings. Scandinavia and Europe AD 700-1100. London: Methuen. https://doi.org/10.4324/9780203407820

Schjødt, J.P., 2003. Initiation, liminalitet og tilegnelse af numinøs viden. En undersøgelse af struktur og symbolik i forkristen nordisk religion. Teologisk Fakultet, Århus Universitet. https://doi.org/10.7146/rt.v0i45.1750

Schultz, M.K., Mortensen, M.F. and Ulriksen, J., in prep. A Viking Age ring fortress and its hinterland - a friendly neighbourhood?

Segschneider, M. 2009. 'Die Ringwälle auf den nordfriesischen Inseln'. In: M. Segschneider, ed. Ringwälle und verwandte Strukturen des ersten Jahrtausends n. Chr. an Nord- und Ostsee. Schriften des archäologischen Landesmuseums. Ergänzungsreihe Band 5. Wachholtz Verlag, 99-111. 
Skaarup, J., 2005. Øhavets middelalderlige borge og voldsteder. Langelands Museum.

Steinsland, G., 1989. Det hellige bryllup og norrøn kongeideologi. En undersøkelse av hierogami-myten $i$ Skirnismál, Ynglingatal, Háleygjatal og Hyndlaljód. Oslo.

Steinsland, G., 2000. Den hellige kongen. Om religion og herskermakt fra vikingetid til middelalder. Oslo.

Stidsing, E., 2016. 'Fra insulært skrinbeslag til spænde'. In H. Lyngstrøm and J. Ulriksen, eds., Død og begravet - i vikingetiden. Artikler fra et seminar på Københavns Universitet den 26. februar 2016. Copenhagen, 36-40.

Szczepanik, P. and Wadyl, S., 2014. A comparative Analysis of Early Medieval North-West Slavonic and West Baltic Sacred Landscapes. An introduction to the Problems. Networks and Neighbours, vol 2, No. $1,2014,1-21$.

Tummuscheit, A. and Witte, F., 2018. 'The Danevirke in the light of recent excavations'. In: J. Hansen and M. Bruus, eds. The Fortified Viking Age. The $36^{\text {th }}$ Interdisciplinary Viking Age Seminar, Odense 2017, 69-74.

Ulriksen, J. 1990. Beretning for udgravningen på Aggersborg, okt./nov. 1990. Nationalmuseet, j.nr. 1102/75. Unpublished report. The National Museum of Denmark.

Ulriksen, J., Krause, C. and Jensen, N.H., 2014. Roskilde - en bygrundlæggelse i vanskeligt terræn. Kuml, 2014, 145-185. 